\title{
La dignidad de la persona como valor supremo del ordenamiento jurídico
}

Francisco FernáNdez SEgado

\section{La dignidad de la persona como valor jurídico fundamental del constitucionalismo de la segunda postguerra.}

Uno de los rasgos sobresalientes del constitucionalismo de la segunda postguerra es la elevación de la dignidad de la persona a la categoría de núcleo axiológico constitucional, y por lo mismo, a valor jurídico supremo del conjunto ordinamental, y ello con carácter prácticamente generalizado y en ámbitos socio-culturales bien dispares, como muestran los ejemplos que más adelante ofrecemos. Ello tiene una explicación fácilmente comprensible. Los errores de la Segunda Guerra Mundial impactarían de tal forma sobre el conjunto de la humanidad, que por doquier se iba a generalizar un sentimiento de rechazo, primero, y de radical rectificación después, que había de conducir en una dirección que entendemos sintetiza con meridiana claridad el primer párrafo del Preámbulo de la Declaración Universal de Derechos Humanos de 10 de diciembre de 1948, en que puede leerse lo que sigue:

«Considerando que la libertad, la justicia y la paz en el mundo tienen por base el reconocimiento de la digna intrínseca y de los derechos iguales e inalienables de todos los miembros de la familia humana»

A partir de esta reflexión, el Art. $1^{\circ}$ de la misma Declaración proclamará que todos los seres humanos nacen libres e iguales en dignidad y derechos, determinación que, como es bien conocido, recuerda muy de cerca el primer inciso del Art $1^{\circ}$ de la Declaración de Derechos del Hombre y del Ciudadano de 26 de agosto de 1789 ( Les hommes naissent et demeurent libres et égaux en droits») y, si seguimos a 
Jellinek ${ }^{1}$, su modelo de los Bills of Rights de los Estados de la Unión norteamericana ${ }^{2}$.

El rasgo precedentemente enunciado, como acabamos de decir, lo hallamos en constituciones de ámbito bien diferentes. Y así, la Constitución del Japón de 1946, en su Art. 13º, proclama que: «Toda persona tendrá el respeto que merece como tal», para añadir de inmediato que: «El derecho a la vida, a la libertad y a la búsqueda de la felicidad serán, en la medida en que no se opongan al bienestar general, la consideración suprema de la legislación y demás asuntos de Gobierno». A su vez, los derechos fundamentales son conferidos a los miembros de la sociedad y de futuras generaciones en calidad de derechos eternos e inviolables. Y aunque se ha afirmado ${ }^{3}$ que el Preámbulo y la declaración de derechos de la Constitución japonesa reflejan mejor las tradiciones y los ideales de la República norteamericana que los del Japón, en base al dirigismo que sobre los constituyentes japoneses ejercieron los Estados Unidos, ello no obsta en lo más mínimo para dejar de apreciar esta sensibilidad humanista.

En un contexto social, cultural y aun religioso tan distinto como es el caso de la República Islámica de Irán, también se aprecia esa sensibilidad. Su Constitución de 1979 tras proclamar en su artículo $2^{\circ}$ que la República Islámica es un sistema establecido sobre la base del respeto a los valores supremos del hombre, determina que: «la persona, la vida, los bienes, los derechos, la dignidad, el hogar y el trabajo de las personas son inviolables».

También en América Latina podemos constatar ese sentido humanista. Recordemos cómo en la Constitución del Perú de 1979, derogada por la hoy vigente de 1993, los constituyentes proclamaban su creencia en la primacía de la persona humana y en que todos los hombres, iguales en dignidad, tienen derechos de validez universal, anteriores y superiores al Estado. Y la actual Constitución de Guatemala de 1985 proclama en su artículo $4^{\circ}$ que todos los seres humanos son libres e iguales en dignidad y derechos, para añadir poco después que ninguna persona

1 JiLlink, Georg, "La Declaración de los Derecbos del bombre y del ciudadano", en G. Jellinek, E. Boutmy, E. Doumergue y A. Posada: Origenes de la Declaración de Derechos del Hombre y del Ciudadano, edición de Jesús G. Amuchástegui, Editora Nacional, Madrid, 1984, pp. 57 y ss.; en especial, pp. 72-76.

2 Recordemos, por ejemplo, que a tenor del punto I de la Declaración de Derechos acogida en la Constitución de Massachusetts, de 2 de Marzo de 1780: ("All men are born free and equal, and bave certain natural, essential and alienable rights).

3 Duchack, Ivo D., Derechos y Libertades en el mundo actual, Instituto de Estudios Políticos, Madrid, 1976, pp. 39. 
pueda ser sometida a servidumbre ni a otra condición que menoscabe su dignidad.

Esa sensibilidad por el ser humano ha tenido hondamente el constitucionalismo occidental europeo, que ha venido a consagrar la dignidad de todo ser humano como valor material central de la Norma fundamental, derivando del mismo un amplísimo reconocimiento de los derechos de la persona y una multiplicidad de mecanismos de garantía.

Este es el caso de la Constitución Italiana, cuyo Art. $2^{\circ}$ proclama que: "La República riconosce e garantisce $i$ diritti inviolabili dell uomo, sia come singolo, sia nelle formazioni sociali ove si solge la sua personalita, $e$ richiele l'adempimento dei doveri inderogabili di soliderieta politica, economica e sociales", con lo que el constituyente, de modo inequívoco, enuncia, como significara Mortati ${ }^{4}$, dos presupuestos irrenunciables de la forma democrática de Estado: el principio personalista y el igualitario. De esta forma, los derechos inviolables del hombre no pueden ser concebidos como la resultante de una autolimitación del Estado Republicano, sino que, como sostiene Paladin ${ }^{5}$, representan «un dato congénito dell'ordinamento statale vigente»; se trata precisamente de aquella decisión que separa al nuevo Estado de la postguerra del Estado totalitario creado por el fascismo. Por lo demás, no es inadecuado recordar que la vigencia efectiva de los derechos del hombre, bien individualmente considerado, bien como integrante de unas formaciones sociales en las que desarrolla su personalidad, requiere del cumplimiento de unos deberes de solidaridad; entre la vigencia de los derechos y el cumplimiento de los deberes se establece una estrecha correlación, por lo que a la "inviolabilita" de los derechos corresponde la "inderogabilita" de los deberes. Y aunque la Constitución no se refiera explícitamente a la dignidad de la persona, debe darse por reconocida en cuanto que los derechos inviolables del hombre son inherentes a esa dignidad y, por lo tanto, se fundan en ella.

La Constitución Italiana va incluso más allá en su finalidad última de alcanzar el pleno desarrollo de la personalidad humana, meta con la que se trata de dar cierta concreción individualizada al reconocimiento de aquellos derechos inviolables. Y en esa dirección ha de situarse la conocida como «cláusula Lelio Basso» del párrafo segundo del Art. 3ำ a

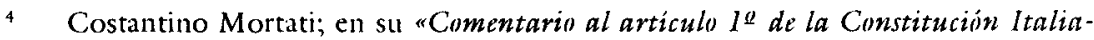
na", en Giuseppe Branca, Comentario della Costituzione, tomo I (Principi fondamentali), Nicola Zanichelli Editore - Soc. Ed. del Foro Italiano, Bologna - Roma, 1975 , pp. 1 y ss.; en concreto, pp. $6-7$.

5 Livio Paladin: Distrito Costituzionale, CEDAM, Padova, 1991, pp. 562-563. 
cuyo tenor: "E compito della Repubblica rimuovere gli ostacoli di ordine economico e sociale, che, limitando di fatto la libertá e l'eguaglianza dei cittadini impediscono il pieno sviluppo della persona umana..."

Una cláusula como la transcrita viene a desmentir, como ya sostuviera el propio diputado italiano a quien se atribuye su paternidad, Lelio Basso, todas aquellas afirmaciones constitucionales que dan por realizado lo que aún está pendiente por realizar (la democracia, la igualdad... etc.). Por ello, el precepto asume una virtualidad jurídica que desborda la propia de un mero mandato al legislador, convirtiéndose en una norma llamada a superar esa flagrante contradicción constitucional mediante la transformación de la propia estructura constitucional en un sentido material ${ }^{6}$.

Los potenciales efectos transformadores de la cláusula en cuestión quedan perfectamente compendiados en un conocido comentario de Calamandrei, para quien: "per compensare le forze di sinistra della rivoluzione mancata, le forze di destra non si opposero ad accogliere nella costituzione una rivoluzione promessar.

La Ley Fundamental de Bonn de 1949 va a dar pasos muy importantes en la misma dirección. Su misma norma de apertura (Art. $\mathfrak{l}^{\circ} .1$ ) proclama solemnemente: "La dignidad del hombre es intangible y constituye deber de todas las autoridades del Estado su respeto y protección", para, en el siguiente apartado el propio artículo (Art. $1^{\circ} .2$ ) añadir: "Conforme a ello, el pueblo alemán reconoce los inviolables e inalienables derechos del hombre como fundamento de toda comunidad humana, de la paz y de la justicia en el mundo". Como ha reconocido el Tribunal Constitucional Federal, este artículo figura entre los principios básicos de la Constitución que dominan todos los preceptos de la Ley Fundamental ${ }^{8}$. Y en otro momento 9 , ha admitido el mismo Tribunal que la dignidad es el valor jurídico supremo dentro del orden constitucional.

La mayor problemática que había de suscitar esta elevación de la dignidad del ser humano a la categoría de núcleo axiológico central del or-

\footnotetext{
6 Romagnol1, Umberto, "Il principio d'uguaglianza sostanziale", en el colectivo editado por Giuseppe Branca, Comentario della Costituzione. Op. cit., vol. $1^{\circledR}$, p. 162 y ss.; en concreto, p. 166.

7 Calamandrei, Piero, Introduzione storica sulla Costituente, en Piero Calamandrei y A. Levi (dirs.) Commentario sistematico alla Constituzione Italiana, Firenze, 1960, vol. $1^{\circ}$, p. CXXXV.

$8 \quad$ BVerfGE, 6, 32 y ss.; en concreto, 36

9 BVerfGE, 45,187 y ss.; en concreto, p. 227.
} 
den constitucional consistía precisamente en definir qué había de entenderse por "dignidad del hombre». Quizá una de las definiciones más citadas sea la de Von Wintrich ${ }^{10}$, para quien la dignidad del hombre consiste en que "el hombre, como ente ético-espiritual, puede por su propia naturaleza, consciente y libremente, autodeterminarse, formarse y actuar sobre el mundo que le rodea». Las dificultades de una definición del concepto de dignidad se documentan en el extremo de que la doctrina jurídico-constitucional no ha llegado todavía a una definición satisfactoria, permaneciendo atrapados los intentos de definición en formulaciones de carácter general ("contenido de la personalidad", "núcleo de la personalidad humana»... $)^{11}$.

No obstante las dificultades precedentemente advertidas, Stein ${ }^{12}$, atendiendo al significado etimológico del término, ha intentado una aproximación al concepto que creemos de utilidad. "Dignidad» ("Wurde») es un abstracto del adjetivo «valor» ("Wert») y significa, originariamente, la materialización de un valor. Según esto, la referencia del Art. $1^{\circ} .1$ habría de entenderse en el sentido de que la cualidad del hombre, como valor, es intangible. Pero como este valor podría ser desplazado por otros valores, Stein considera que para evitar esta posibilidad, la significación del Art. $1^{\circ} .1$ ha de ser la de que el hombre es el valor supremo, tesis concordante con la apuntada, como vimos antes, por el Tribunal Constitucional.

Por lo demás, la interpretación precedente casa a la perfección con la formulación constitucional del Art. $1^{\circ} .2$ de la «Bonner Grundgesetz». En efecto, en cuanto el hombre es el valor supremo, el referente axiológico central de todo el orden constitucional, el pueblo alemán reconoce los derechos inviolables e inalienables del hombre, elevándolos a la categoría de fundamento de toda comunidad humana, de la paz y de la justicia en el mundo. Y de ello, a su vez, se hace derivar (Art. I .3) el principio de vinculatoriedad inmediata de los derechos fundamentales: "los derechos fundamentales que se enuncian a continuación vinculan al Poder Legislativo, al Poder Ejecutivo y a los Tribunales a título de derecho directamente aplicable».

10 Von Wintrich: «Zur Problematik der Grundrechte», 1957, p. 15. Cit. por Ekkehart Stein: Lebrbuch des Staatsrechts, Tubingen, 1968. Traducción espanola de F. Sainz Moreno, bajo el título Derecho Político, Aguilar, Madrid, 1973, p. 236.

1 Ingo von Munch: «La dignidad del hombre en el Derecho constitucional» en «Revista Española de Derecho Constitucional», $\mathrm{N}^{\circ}$ 5, mayo-agosto 1982, p. 9 y ss.; en concreto, p. 19.

$12 \quad$ Ekkehart Stein: Derecho Politico. Op. cit., p. 237. 
Los derechos fundamentales son inherentes a la dignidad del ser humano y, por lo mismo, se fundan en ella y, a la par, operan como el fundamento último de toda comunidad humana, pues sin su reconocimiento quedaría conculcado ese valor supremo de la dignidad de la persona en el que ha de encontrar su sustento toda comunidad humana civilizada.

A la par, como ya indicamos, la dignidad de la persona bien puede entenderse que consiste o, por lo menos, que entraña ineludiblemente la libre autodeterminación de toda persona para actuar en el mundo que la rodea. Y en perfecta sintonía con esta exigencia, el Art. $2^{\circ} .1$ de la Ley Fundamental de Bonn reconoce el derecho de cada persona al libre desenvolvimiento de su personalidad, en tanto no vulnere los derechos de otro y no atente al orden constitucional o a la ley moral.

Y si nos referimos por último a la Constitución de la República Portuguesa de 1976, su Art. I o comienza afirmando que "Portugal é uma República soberana, baseada na dignidade da pessoa humana...", lo que ha conducida a Miranda ${ }^{13}$ a considerar que la Constitución confiere una unidad de sentido, de valor y de concordancia práctica al sistema de los derechos fundamentales, que a su vez descansa en la dignidad de la persona humana, o sea, en una concepción que hace de la persona fundamento y fin de la sociedad y del Estado.

\section{La proclamación constitucional de la dignidad de la persona en el artículo 10.1 de la Constitución Española de 1978}

\section{A. Génesis del precepto}

El Art. 10, norma de apertura del Título primero, proclama en su apartado uno que: «La dignidad de la persona, los derechos inviolables que le son inherentes, el libre desarrollo de la personalidad, el respeto a la ley y a los derechos de los demás son fundamento del orden político y de la paz social».

Frente a la omisión de todo orden material de valores que inspirase el ordenamiento jurídico en el régimen franquista, la Ley para la Reforma Política, de 4 de enero de 1977, acogía un cambio radical de pers-

13. Mrranda, Jorge, Manual de Direito Constitucional, tomo IV ("Direitos fundamentais»), 2a. ed., Coimbra Editora, Limitada, Coimbra, 1993, p. 166. 
pectiva en este punto al determinar en el inciso segundo de su Art. $1^{0} .1$ : «Los derechos fundamentales de la persona son inviolables y vinculan a todos los órganos del Estado", previsión que puede considerarse como el antecedente más inmediato del Art. 10.1 de nuestra Norma suprema.

De la necesidad, carácter no redundante y trascendencia política del precepto en cuestión se haría eco la doctrina ${ }^{14}$, que también pondría de relieve que una norma de esta naturaleza supone, ante todo, un correctivo al voluntarismo jurídico y a la omnímoda hegemonía de la ley, así como un reconocimiento de que el poder, en sus orígenes y en su ejercicio, es inseparable de la idea de límite, y el límite, en su base esencial, descansa en los derechos fundamentales que designan como centro de producción a la persona ${ }^{15}$.

En definitiva, el precepto mencionado de la Ley para la Reforma Política venía a entrañar un freno radical frente a todo voluntarismo jurídico, una quiebra de las bases mismas del positivismo jurídico, un rechazo de cualquier cobertura formalmente democrática frente a la arbitrariedad de una mayoría contraria a los más elementales valores inherentes a la persona humana, y una reafirmación de que la persona no es un mero reflejo de la ordenación jurídica, sino que, bien al contrario, tiene una existencia previa, y aunque es evidente que el ordenamiento jurídico habrá de dotarla de significación, no lo es menos que en ningún caso podrá ignorar esa preexistencia que se manifiesta en el hecho de que de la persona dimanan unos derechos inviolables que han de ser considerados como inherentes a ella.

A partir del precedente anterior, la Ponencia Constitucional incorporaba al Anteproyecto de Constitución un artículo, el 13, del siguiente tenor: "La dignidad, los derechos inviolables de la persona humana y el libre desarrollo de la personalidad, son fundamento del orden político y de la paz social, dentro del respeto a la ley y a los derechos de los demás» ${ }^{16}$.

Un total de ocho enmiendas se presentarían al texto anterior. De ellas, sólo una, la número 63 , del Sr. Fernández de la Mora, postularía

14 Gonzallz Navarro, Francisco, La nueva Ley Fundamental para la Reforma Política, Secretaría General Técnica, Presidencia del Gobierno, Colección Informe, $\mathrm{N}^{2} 14$, Madrid, 1977, p. 110.

15 Hernánilez Gil, Antonio, El cambio politico español y la Constitución, Planeta, Madrid, 1982, p. 148.

16 Boletín Oficial de la Cortes, $N^{2} 44,5$ de enero de 1978, pp. 669 y ss.; en concreto, p. 671 . 
su supresión sobre la base de considerar que el precepto en cuestión no establecía ningún derecho y abarcaba una definición sobre materia no constitucional. Bien es verdad que otra enmienda, la número 2 , del $\mathrm{Sr}$. Carro Martínez, propugnaba la eliminación de algunos de los contenidos de mayor trascendencia del precepto ${ }^{17}$. Ninguna de ellas sería aceptada por la Ponencia, al entender que los principios reconocidos «son la base para el desarrollo de las libertades públicas en los artículos siguientes» ${ }^{18}$. Tampoco aceptaría la Ponencia, por mayoría, la supresión de la expresión «paz social», solicitada por algunas de las restantes enmiendas. No obstante, la Ponencia, por mayoría, procedía a dar una nueva redacción al artículo, ordenando de una manera más precisa técnicamente los conceptos en él contenidos, situando además al precepto como introductorio del Título primero de la Constitución, relativo a los derechos y deberes fundamentales. Esa nueva redacción sería a la postre la definitiva, puesto que el precepto en cuestión ya no sufriría modificación alguna a lo largo del «iter» constituyente.

\section{B. Dignidad de la persona y orden valorativo}

I. Una lectura detenida del texto del Art. 10.1 nos revela que la dignidad de la persona es el primer principio en que están contenidas, como en su simiente, las demás afirmaciones. Como recuerda Sánchez Agesta $^{19}$, los derechos inviolables de la persona, en cuanto inherentes a su dignidad, se fundan en ella. A su vez, el libre desarrollo de la personalidad da un carácter concreto, individualizado, a esa floración de derechos dimanantes de la dignidad personal. Por último, el respeto a los derechos de los demás no es sino la resultante obligada de la afirmación primigenia, esto es, de que la dignidad es patrimonio común de todos y cada uno de los seres humanos, sin excepción alguna. Y en cuanto al respeto a la ley, debe entenderse en el sentido de que la ley es la norma que regula la convivencia pacífica sin la que carecería de sentido hablar de paz social, de esos seres humanos que, ejercitando los derechos inviolables que le son inherentes, desarrollan libremente su personalidad.

\footnotetext{
17 El texto que proponía la enmienda $N^{e} 2$ del Sr. Carro Martínez, era el que sigue: «Las libertades públicas, dentro del respeto a la Ley y a los derechos de los demás, son fundamento del orden político y de la paz social».

18 Boletín Oficial de la Cortes, N2 82, 17 de Abril de 1978, p. 1530.

19 SÁNchliz Acifsta, Luis, El sistema político de la Constitución Española de 1978, Editora Nacional, Madrid, 1980, p. 73.
} 
El precepto supone la consagración de la persona y de su dignidad no sólo como el fundamento de la totalidad del orden político, sino, y precisamente por ello mismo, también como el principio rector supremo del ordenamiento jurídico. Se condensa aquí, en clave principal, dirá Parejo ${ }^{20}$, la filosofia, los criterios axiológicos a que responde por entero y que sustentan el orden dogmático constitucional.

El valor último, el principio nuclear, es, como ya ha quedado dicho, la dignidad humana, sin connotación o conexión alguna con un determinado orden económico o social, pero valorada evidentemente como valor propio del individuo en sociedad. Como dijera Goldschmidt ${ }^{21}$, cada persona humana individual es una realidad en sí misma, mientras que en el Estado no es más que una realidad accidental, ordenada como fin al bien de las personas individuales; consecuentemente, es del todo oportuno afirmar que el derecho fundamental para el hombre, base y condición de todos los demás, es el derecho a ser reconocido siempre como persona humana ${ }^{22}$.

En cuanto la democracia, como bien afirmara Maritain ${ }^{23}$, es una organización racional de libertades fundada en la ley, y en cuanto la libertad es indivisible y se asienta en la libertad fundamental del individuo, en un derecho radical, entre los fundamentales, del que, como recuerda Peces Barba $^{24}$, traen su causa los demás, esto es, en el derecho a ser considerado como ser humano, como persona, es decir, como ser de eminente dignidad, titular de derechos y obligaciones, el Derecho, el ordenamiento jurídico en su conjunto no quedará iluminado -en términos de Lucas Verdú ${ }^{25}$-, legitimado, sino mediante el reconocimiento de la dignidad de la persona humana y de los derechos que le son inherentes, lo que nos permite hablar de la existencia de un sustrato filosófico iuspersonalista que, a nuestro modo de ver, se alimenta ideológicamente

20 Luciano Parejo, Alfonso, Estado social y Administración Pública, Civitas, Ma drid, 1983, p. 71.

21 Goloschmint, Werner, Introducción Filosófica al Derecho, Depalma, 6a. edición Buenos Aires, 1983, p. 543.

22 Legaz Lacambra, Luis, "La noción juridica de persona humana y los derechos del hombre", en Revista de Estudios Politicos, No 55, enero-febrero 1951, pp. 15 y ss.; en concreto, p. 44.

2.3 Maritain, Jacques : El hombre y el Estado, Encuentro Ediciones, Madrid, 1983, p. 75 .

24 Pecls BARlia, Gregorio, Derechos Fundamentales, Latina Universitaria, 3a. edición, Madrid, 1980, p. 91.

25 Lucas Vernú, Pablo, Curso de Derecho Político, Vol. IV, Tecnos, Madrid, 1984, p. 320 . 
de las aportaciones del liberalismo, del socialismo democrático y del humanismo social-cristiano.

Este iuspersonalismo se manifiesta socialmente en lo que se ha denominado ${ }^{26}$ el "personalismo comunitario», esto es, en una comunidad social plural. Es desde esta perspectiva como cobran su pleno sentido todos y cada uno de los valores que enuncia el Art. $1^{\circ} .1$ de nuestra Carta Magna: la libertad, la igualdad, la justicia y el pluralismo político. Es cierto que desde diferentes sectores de pensamiento se ha tratado de relativizar alguno de esos valores ${ }^{27}$; sin embargo, a nuestro juicio, no sólo no debe excluirse ninguno, sino que todos y cada uno de ellos se complementan de algún modo entre sí.

De la dignidad de la persona fluye el principio de libertad, valor que, como ya significara Recaséns Siches ${ }^{28}$, asegura un contenido valorativo al Derecho. Pero es que, además, la libertad y, sobre todo, la igualdad forman parte del contenido y del fin de la justicia ${ }^{29}$; incluso se ha tendido a considerar identificados los valores justicia e igualdad; sin embargo, la justicia, en cuanto valor social por excelencia, es un criterio de valoración destinado a conformar el comportamiento social. En definitiva, la justicia tiene un sentido de totalidad que le lleva a ser no sólo valor, en sí, sino también medida de los demás valores sociales y jurídicos. Por lo demás, el valor absoluto de la justicia, dar a cada uno "lo suyo»", se en-

\footnotetext{
26 Ibidem.

27 Es el caso de Gregorio Peces Barba (en "Reflexiones sobre la Constitución española desde la Filosofía del Derecho", en Revista de la Facultad de Derecho de la Universidad Complutense, $\mathrm{N}^{2} 61$, invierno 1981 , p. 95 y ss.; en concreto, pp. 123-124), quien, tras relativizar la necesidad de la presencia del valor "pluralismo político", ha entendido que "la justicia es también un término innecesario y reiterativo con los términos libertad e igualdad, que constituyen hoy el contenido material de la idea de justicia", reflexión que contrasta con la que, obviamente al margen de la Constitución, sostuvieron Castán Tobenas (en Los derechos del hombre, 3i. edición, Reus, Madrid, 1985, p. 61), para quien las nociones de libertad e igualdad son dependientes de la idea de justicia, pues al proyectarse el ideal de justicia sobre aquellas -admite Castán, siguiendo en ello a Ruiz del Castillo (Manual de Derecho Político, Reus, Madrid, 1939, p. 344-), llena de significación esas ideas que, de otro modo, serían inexplicables.

${ }_{28}$ Rrcistins Siches, Luis, Introducción al estudio del Derecho, Porrúa, México, 1981, p. 334.

29 Hernández GiL, Antonio, El cambio político.... Op. cit., p. 382.

30 Creemos que este valor absoluto es perfectamente compaginable con esa dimensión dinámica a que aludiera Carl J. Friedrich (en «La Filosofía del Derecho", FCE, la. edición., 3a reimpr., México, 1982, p. 286) que se refería a cómo podía comprenderse la justicia como una realidad cambiante, cuyos cambios ocurren en respuesta al proceso dinámico de la política.
} 
cuentra indestructiblemente vinculado con la dignidad de la persona, en cuanto que cada individuo tiene un fin propio que cumplir, fin intransferible y privativo al que parece apuntar al texto constitucional cuando alude al «libre desarrollo de la personalidad», esto es, a lo que bien puede entenderse con Ruiz-Giméne $z^{31}$ como el despliegue de las diferentes potencialidades (psíquicas, morales, culturales, económicas y sociales) de cada ser humano, la conquista de los valores que le satisfagan y de los ideales que le atraigan; el alcance, en suma, de su modelo de ser humano y de miembro activo protagonista en una sociedad determinada.

Y es aquí donde entra en juego el valor "pluralismo político", que aunque con una proyección básicamente estructural, desborda con creces tal perspectiva para incidir de modo muy positivo en que cada ser humano pueda desarrollar en libertad su personalidad. El pluralismo ínsito a cualquier colectivo social no sólo debe ser respetado por el ordenamiento jurídico, sino que éste debe venir informado por aquél.

En resumen, el Art. 10.1, desde el punto de vista axiológico, eleva la dignidad de la persona a la categoría de "Grundnorm" en sentido lógico, ontológico y deontológico ${ }^{32}$; justamente por ello, los restantes valores que proclama la Norma suprema han de tener como referente necesario la dignidad de la persona, encontrando en ella su razón de ser última.

II. Las reflexiones precedentes parecen situarnos ante una evidencia: nos hallamos en presencia de un precepto en el que la filosofia política hace acto de presencia de un modo harto elocuente; una filosofia política, que por lo demás no es patrimonio exclusivo de ninguna ideología, penetra de esta forma en el ordenamiento jurídico, y ello, de inmediato, nos plantea la cuestión de si el precepto debe ser entendido en clave iusnaturalista o en clave positivista. Dicho de otra forma, los postulados del Art. 10.1, y muy específicamente los tres primeros, ¿tienen carácter suprapositivo, habiendo de considerarse, por su proximidad al pensamiento filosófico iusnaturalista, según criterios iusnaturalistas?, o por el contrario, en cuanto que los textos normativos que tienen su origen en

\footnotetext{
31 Ruiz-Giméniz Cortés, Joaquín, "Derechos fundamentales de la persona" (Comentario al artículo 10 de la Constitución), en Oscar Alzaga (dir.) Comentario a las Leyes Politicas, tomo I, Editorial Revista de Derecho Privado, Madrid, 1984, pp. 45 y ss.; en concreto p. 123.

32 Lucas Vrrou, Pablo, Estimativa y politica constitucionales (Los valores y los principios rectores del ordenamiento constitucional español), Universidad de Madrid, Facultad de Derecho, Madrid, 1984, p. 117).
} 
las primeras Declaraciones de Derechos de fines del siglo XVIII han venido recogiendo esos valores, positivándolos, y así han llegado hasta nuestros días, en los que es común la constitucionalización de esos grandes valores, plenamente enraizados en los ordenamientos jurídicos, ¿tales principios han de ser entendidos en clave meramente positivista?.

Desde luego, es indudable que la proclamación que el Art. 10.1 hace de la dignidad de la persona, elevándola a la categoría de fundamento del orden político y de la paz social no tiene otro sustento que la propia voluntad de la Nación española de la que hace eco el Preámbulo de la Constitución. Pero como dice González Pérez ${ }^{33}$, es indudable que las mismas expresiones "dignidad de la persona», "derechos inviolables» y "libre desarrollo de la personalidad" suponen la vinculación en una concepción iusnaturalista. Y en análoga dirección se manifiesta la mayoría de la doctrina. Y así, por poner un ejemplo concreto, Pérez Luño ${ }^{34}$, de modo rotundo considera que nuestra Constitución se inserta abiertamente en una orientación iusnaturalista, en particular de la tradición objetivista cristiana, que considera los derechos de la persona como exigencias previa a su determinación jurídico-positiva y legitimadoras del orden jurídico y político en su conjunto. Dicha inspiración iusnaturalista constituye la innegable fuente del Art. 10.1.

Por nuestro lado, creemos con Bachof ${ }^{55}$ que el orden material de valores de nuestra Constitución, como el de la "Bonner Grundgesetz) a que se refiriera dicho autor, ha sido considerado por la Constitución como anterior a ella misma por cuanto no ha sido creado por la Constitución, sino que ésta se ha limitado a reconocerlo y garantizarlo, pues su último fundamento de validez se encuentra en los valores determinantes de la cultura occidental, en una idea del hombre que descansa en esos valores. $Y$ en conexión con esta idea, entendemos que bien podría hablarse de la existencia de unos límites inmanentes a la reforma constitucional, cuyo punto focal sería sin ningún género de dudas el Art. 10.1, que bien podríamos considerar como revestido de una suerte de inmunidad frente a su supresión o frente a cualquier reforma que lo desnaturalizara. Bien es verdad que, como reconociera Loewenstein ${ }^{36}$, el problema

33. Gonzálhz Pérez, Jesús, La dignidad de la persona,. Editorial Civitas Madrid, 1986, p. 81 .

34 Pf́rkz Luño, Antonio E., Los derechos fundamentales, Editorial Tecnos, Madrid, 1984, p. 115.

35 BaCHor, Otto, Jueces y Constitución, Civitas, Madrid, 1985, pp. 39-40.

36 Lobwenstrin, Karl, Teoría de la Constitución, 2a. edición, Ediciones Ariel, Barce lona, 1970, p. 193. 
que ahora planteamos no es tanto un problema jurídico cuanto una cuestión de creencias donde no se puede argumentar racionalmente, aún cuando por necesidades prácticas de la convivencia en la comunidad humana está revestida de formas jurídicas. Y es que la cuestión de fondo es la de si estos valores y los derechos fundamentales que de ellos dimanan son traídos consigo por el hombre con su nacimiento a la sociedad estatal, o si por el contrario son otorgados por la sociedad estatal en virtud del orden de la comunidad.

\section{Caracterización de la Dignidad de la Persona}

Ya en un momento anterior hemos puesto de manifiesto las dificultades existentes para llegar a un concepto de lo que ha de entenderse por dignidad de la persona, dificultades que explican el hecho de que, por ejemplo todavía en Alemania, como recuerda Von $\mathrm{Munch}^{37}$, los intentos de definición permanezcan atrapados en formulaciones de carácter general, de las que constituyen buenos ejemplos su caracterización como «núcleo de la personalidad humana» o como «contenido de la personalidad».

No han faltado quienes entienden (entre otros, Nipperdey, Neumann y Scheuner) que la dignidad de la persona no es un concepto jurídico y significa una apelación a la esencia de la naturaleza humana.

En cualquier caso, en una primera aproximación al concepto, podemos diferenciar dos sentidos en el mismo: una determinada forma de comportamiento de la persona, presidida por su gravedad y decoro, a tenor del Diccionario de la Real Academia ${ }^{38}$, y una calidad que se predica de toda persona, con independencia ya de cual sea su específica forma de comportamiento, pues ni tan siquiera una actuación indigna priva a la persona de su dignidad. Como dice González Pérez $z^{39}$, la dignidad es el rango o la categoría que corresponde al hombre como ser dotado de inteligencia y libertad, distinto y superior a todo lo creado, que comporta un tratamiento concorde en todo momento con la naturaleza humana.

La dignidad exige, pues, dar a todo ser humano lo que es adecuado a su naturaleza misma de hombre como ser personal distinto y superior

\footnotetext{
37 Von Munch, Ingo, La dignidad del hombre en el Derecho Constitucional. Op. cit., p. 19.

38 Real Academia Española: Diccionario de la Lengua Española, 20a. edición, tomo I. Madrid, 1984, p. 499.

39 González Pérfz, Jesús, La dignidad de la persona. Op. cit., p. 112.
} 
a todo ser animal, en cuanto dotado de razón, de libertad y de responsabilidad. Justamente por ello, la dignidad debe traducirse en la libre capacidad de autodeterminación de toda persona, que, como dijera el Tribunal Constitucional Federal Alemán en una conocida Sentencia de 15 de diciembre de $1983^{40}$, presupone que se conceda al individuo la libertad de decisión sobre las acciones que vaya a realizar o, en su caso, a omitir, incluyendo la posibilidad de obrar de hecho en forma consecuente con la decisión adoptada.

En una posición más casuística y minuciosa, Ruiz-Giméne ${ }^{41}$ ha distinguido cuatro niveles o dimensiones en la dignidad personal: a/ la dimensión religiosa o teológica, para quienes creemos en la relegación del ser humano con Dios, que entraña un vínculo de filiación y de apertura a El, como "hechos a su imagen y semejanza»; b/ la dimensión ontológica, como ser dotado de inteligencia, de racionalidad, libertad y consciencia de sí mismo; $\mathrm{c} /$ la dimensión ética, en el sentido de autonomía moral, no absoluta, pero sí como esencial función de la conciencia valorativa ante cualquier norma y cualquier modelo de conducta; y de esfuerzo de liberación frente a interferencias o presiones alienantes y de manipulaciones cosificadoras, y d/ la dimensión social, como estima y fama dimanante de un comportamiento positivamente valioso, privado o público, en la vida de relación. A partir de estos niveles, Ruiz-Giménez entiende con buen criterio que las dimensiones primordialmente asumibles por quienes hayan de aplicar la pauta normativa del Art. 10.1 de la Constitución son la de carácter ontológico (racionalidad y libertad del ser humano) y la de carácter ético profundo (autonomía y fin de si mismo, no medio o instrumento de nadie).

En resumen, de lo hasta aquí expuesto se desprende que la dignidad, en cuanto calidad ínsita a todo ser humano y exclusiva del mismo, se traduce primordialmente en la capacidad de decidir libre y racionalmente cualquier modelo de conducta, con la consecuente exigencia de respeto por parte de los demás. No muy diferente ha sido la doctrina sentada por el Tribunal Constitucional, que tras considerar a la dignidad substancialmente relacionada con la dimensión moral de la vida humana, entiende que la dignidad es un valor espiritual y moral inherente a la persona, que se manifiesta singularmente en la autodeterminación cons-

40 Puede verse esta Sentencia en el Boletín de Jurisprudencia Constitucional, No 33, enero 1984, pp., $126-170$.

${ }^{41}$ Ruiz - Giménez Cortis, Joaquín, Derechos fundamentales de la persona, Op. cit., pp. $113-114$. 
ciente y responsable de la propia vida y que lleva consigo la pretensión al respeto por parte de los demás ${ }^{42}$.

Si como acabamos de exponer, no deja de resultar notablemente dificultoso determinar de modo plenamente satisfactorio qué es la dignidad de la persona humana, no faltan autores que entienden, por contra, que manifiestamente sí es posible fijar cuándo se vulnera la dignidad. Y así, Von $\mathrm{Munch}^{43}$, a la vista de la doctrina y de la jurisprudencia alemanas entiende que la dignidad entraña la prohibición de hacer del hombre un objeto de la acción estatal. El Tribunal Constitucional Federal, a la vista de que la persona individual es frecuentemente objeto de medios por parte del Estado, sin que por ello se viole siempre su dignidad, ha matizado la anterior reflexión en el sentido de que sólo se produce una conculcación de la dignidad de la persona cuando el tratamiento como objeto se suma una finalidad subjetiva: sólo cuando el tratamiento constituye "expresión del desprecio" de la persona, o hacia la persona, aprecia el citado Tribunal una vulneración de la dignidad personal.

Entre nosotros, González Pérez ${ }^{44}$ ha enumerado un conjunto de criterios a los que habrá que atender para apreciar cuándo se atenta contra la dignidad de una persona. Creemos que vale la pena recordarlos: a/ en primer término, son indiferentes las circunstancias personales del sujeto, pues la dignidad se reconoce a todas las personas por igual y con carácter general, reflexión plenamente compatible con la matización realizada por el Tribunal Constitucional, para el que cuando el intérprete constitucional trata de concretar el principio de dignidad no puede ignorar el hecho obvio de la especificidad de la condición femenina ${ }^{45}$; b/ en segundo lugar, no se requiere intención o finalidad para que pueda apreciarse la conculcación de este valor fundamental. Si objetivamente se menoscaba el respeto debido a la condición humana, es irrelevante la intencionalidad del agente; $c$ / en tercer término, resulta igualmente irrelevante la voluntad de la persona afectada, y d/ por último, es preciso valorar las diferentes circunstancias concurrentes llegado el momento de calificar una determinada conducta.

42 Sentencia del Tribunal Constitucional (en adelante STC) $53 / 1985$, de 11 de abril, fundamento jurídico $8^{\circ}$.

4.3 Von Munch, Ingo, La dignidad del hombre en el Derecho Constitucional. Op. cit., pp. 19-21. 


\section{Naturaleza y virtualidad del mandato acogido en el Art. 10.1}

Aunque, como ha dicho Hernández $\mathrm{Gil}^{46}$, si hubiéramos de buscar en la Constitución el precepto menos parecido a una norma de conducta u organizativa, sería preciso citar el Art. 10.1, lo cierto es que no estamos en modo alguno ante una mera definición doctrinal o ideológica, ni mucho menos ante una cláusula de limitada o nula eficacia práctica, salvedad hecha de su valor didáctico ${ }^{47}$. Ciertamente que, como ha puesto de relieve Basile ${ }^{48}$, su ubicación al inicio del Título I constituya lo que en términos platónicos se llamaría el "preludio», o sea, la explicación racional que precede a las leyes para que sus destinatarios se persuadan de la bondad de los imperativos que contienen. $Y$ de aquí precisamente vendría su tono didáctico. Pero como el propio Basile recuerda, la experiencia alemana e italiana aconseja, sin embargo, una mayor cautela, porque demuestra que los jueces constitucionales no se detienen ante ninguna declaración constitucional por genérica que sea o por privada de carácter imperativo que parezca.

El precepto, de entrada, nos pone de relieve que la persona es un «prius» respecto de toda ordenación jurídico-positiva, existe en cuanto tal ${ }^{49}$; por lo mismo, los derechos le son inherentes y constituyen el fundamento de toda comunidad humana. De este principio ha de partir el poder del Estado. Y es a todas luces una evidencia, bien que muchas veces ignorada, olvidada o transmutada, que el hombre no existe para el Estado, sino que es el Estado el que existe para el hombre. Y en perfecta coherencia con lo anterior, el Derecho existe menos por el hombre que para el hombre. Y como dice Stein ${ }^{50}$, si el hombre es el valor supremo, los presupuestos de lo humano se hallan bajo la protección estatal más enérgica. Tales presupuestos consisten, sobre todo, en la personalidad del hombre, en el sentido de su autodeterminación, y su conexión

\footnotetext{
46 Hernández Gil, Antonio, El cambio político español y la Constitución. Op. cit., p. 419.

47 Alzaga, Oscar, Comentario sistemático a la Constitución Española de 1978, Ediciones del Foro, Madrid, 1978, p. 156.

4* Basile, Silvio, "Los valores superiores, los principios fundamentales y los derechos $y$ libertades públicas», en Alberto Predieri y E. García de Enterría (dirs.), La Constitución Española de 1978. Estudio sistemático. Editorial Civitas, 2a. ed., Madrid, 1981, pp. 263 y ss.; en concreto, p. 273.

49 Hernánidez Gil, Antonio, El cambio político español... Op. cit., p. 422.

50 STEIN, Ekkchart, «Derecho Político». Op. cit., p. 237-238.
} 
social en el sentido de su tendencia a la comunicación de los demás hombres ${ }^{51}$.

Retornando al Art. 10.1, en él, como se ha puesto de relieve ${ }^{52}$, aun en defecto de que se quisiere entender otra cosa, debe advertirse por lo menos el rechazo de toda visión totalizadora de la vida social; en especial, el rechazo de la idea de organismos colectivos que tengan fines o vida superiores a los de los individuos que los componen. Pero es que, por otra parte, decir que la dignidad de la persona es el fundamento del orden político y de la paz social, no es sólo, como razona Hernández $\mathrm{Gil}^{53}$, formular un precepto con fuerza obligatoria para los ciudadanos y los poderes públicos, sino mostrar al exterior, en términos reflexivos explicativos y esclarecedores, cómo entiende el legislador constituyente el fundamento del orden político y de la paz social. Cuando la Constitución establece la dignidad de la persona es fundamento de la paz social, pone de manifiesto que ésta no es conseguible sin la dignidad de la persona, o lo que es lo mismo; no hay paz social sin dignidad de la persona y no hay dignidad de la persona si falta la paz social.

El Tribunal Constitucional, bien que con excesivas cautelas, ha tenido oportunidad de pronunciarse en algunas ocasiones en torno al Art. 10.1. A su juicio ${ }^{54}$, el tenor del mismo no significa ni que todo derecho sea inherente a la persona -y por ello inviolable- ni que los que se califican de fundamentales sean "in toto" condiciones imprescindibles para su efectiva incolumidad de modo que de cualquier restricción que a su ejercicio imponga devenga un estado de indignidad. Proyectada sobre los derechos individuales, la regla del Art. 10.1 implica que en cuanto «valor espiritual y moral inherente a la persona» (STC 53/1985), la dignidad ha de permanecer inalterada cualquiera que sea la situación en que la persona se encuentre (también, qué duda cabe, durante el cumplimiento de una pena privativa de libertad), constituyendo, en consecuencia, un «minimum invulnerable» que todo estatuto jurídico debe asegurar, de modo que, sean unas u otras las limitaciones que se impongan en

51 Como señala Eusebio Fernández (en: "El problema del fundamento de los derechos bumanos", en Anuario de Derechos Humanos, 1981, Universidad Complutense, Madrid, enero 1982, pp. 73 y ss.; en concreto, p. 98), los derechos humanos aparecen como derechos morales, es decir, como exigencias éticas y derechos que los seres humanos tienen por el hecho de ser hombres $y$, por tanto, con un derecho igual a su reconocimiento, protección y garantía por parte del poder político y del Derecho.

52 Basilt, Silvio, Los valores superiores, los principios fundamentales... Op. cit., pp. $273-274$.

5.3 Hernández Gil, Antonio, El cambio político español..., Op. cit., p. 421.

54 STC $120 / 1990$, de 27 de junio, fund. jur. $4^{2}$. 
el disfrute de derechos individuales, no conlleven menosprecio para la estima que, en cuanto ser humano, merece la persona.

Por lo demás, el «intérprete supremo de la Constitución» ha dejado inequívocamente claro que las normas constitucionales relativas a la dignidad de la persona y al libre desarrollo de la personalidad consagradas en el Art. 10.1 (de la misma forma que los valores superiores recogidos en el Art. 10.1) integran mandatos jurídicos objetivos y tienen un valor relevante en la normativa constitucional, tras lo que el Alto Tribunal ha precisado que tales normas no pretenden la consagración constitucional de ninguna construcción dogmática, sea jurídico-penal o de cualquier otro tipo, y por lo mismo, no cabe fundar la inconstitucionalidad de un precepto en su incompatibilidad con doctrinas o construcciones presuntamente consagradas por la Constitución; tal inconstitucionalidad derivará, en su caso, de que el precepto en cuestión se oponga a mandatos o principios contenidos en el código constitucional explícita o implícitamente $^{55}$.

En definitiva, es claro que el Art. 10.1, aun cuando, si se quiere dentro de un estilo lingüístico más propio de una proposición descriptiva que de otra prescriptiva, presenta un valor que desborda el de una mera declaración rectora de la conducta social de los titulares de los poderes públicos, teñida de una alta carga didáctica, para integrar una auténtica norma jurídica vinculante, un mandato jurídico objetivo que a todos, ciudadanos y poderes públicos, vincula y que reviste una notable relevancia política y, desde luego, jurídica, como se desprende de las diversas funciones que un precepto de esta naturaleza está llamado a cumplir.

Ruiz-Giménez ${ }^{56}$ ha puesto de relieve la triple función que a su juicio cumple el Art. 10.1 de nuestra «lex superior».

a/ En primer término, una función legitimadora del orden político, en sí mismo, y del ejercicio de todos los poderes públicos, por cuanto únicamente será legítimo nuestro orden político cuando respete y tutele la dignidad de cada una y de todas las personas humanas radicadas en su órbita, sus derechos inviolables y el libre desarrollo de su personalidad.

El Art. 10.1 convierte, pues, a la persona y a su dignidad en el elemento de la legitimación del orden político en su conjunto y, justamente por ello, en el principio rector supremo del ordenamiento jurídico,

\footnotetext{
55 STC $150 / \mathrm{P} 1991$, de 4 de julio, fundamento jurídico $4^{2}$.

56 Ruiz-Giménfz Cortes, Joaquín, Derechos fundamentales de la persona. Op. cit., pp. $101-105$.
} 
como ya tuvimos oportunidad de señalar. Estamos en presencia de uno de esos principios de De Castro ${ }^{57}$ considerada como la expresión de la voluntad rectora del Estado, que al ser constitucionalizado adquiere la eficacia propia de una norma directa e inmediata aplicable, con lo que allá: entraña de eficacia invalidatoria, esto es, de considerar que toda norma que contravenga e ignore la dignidad de la persona habrá de ser considerada nula. Pero con ser ello importante, la eficacia del principio desborda este efecto para venir a operar como «fuerza ordenadora de las disposiciones jurídicas» ${ }^{58}$, esto es, como norma directriz que ha de guiar la actuación del legislador en particular y, más ampliamente aún, de todos los poderes públicos en general.

b/ En segundo lugar, una función promocional, en cuanto que ni la dignidad de la persona, ni los derechos inviolables a ella inherentes son elementos estáticos, fijados de una vez para siempre, sino dinámicos, abiertos a un constante enriquecimiento, de lo que bien ilustra la explícita referencia del Art. 10.1 al «libre desarrollo de la personalidad», a la que hay que añadir la cláusula interpretativa de las normas relativas a los derechos fundamentales y a las libertades que la Constitución reconoce, del Art. 10.2 de la Norma Suprema, en la que hay que ver, como muestra a las claras su origen y génesis en el «iter» constituyente, una cláusula de tutela y garantía de los derechos, enderezada a salvar las dificultades de interpretación de los derechos constitucionalmente reconocidos, recurriendo al efecto a las normas de los tratados internacionales en materia de derechos humanos ${ }^{59}$. En el ámbito de esta función bien puede en-

57 Dr. Castro, Federico, Derecho Civil de España, Editorial Civitas, Madrid, 1984, tomo I, p. 424.

5* Ibidem, p. 427.

5) La trascendencia de la cláusula del artículo 10.2 de la Constitución se acentúla si se advierte que, en cuanto «marco de coincidencias lo suficientemente amplio como para que dentro de él quepan opciones politicas de muy diferente signo» (STC 11/1981, de 8 de abril, fund. jur. $7^{9}$ ), la Constitución se limita a consagrar los derechos, otorgarles rango constitucional y atribuirles las necesarias garantías, correspondiendo por ello al legislador ordinario, que es el representante en cada momento histórico de la soberanía popular, confecciona una regulación de las condiciones de ejercicio de cada derecho, que serán más restrictivas o más abiertas, de acuerdo con las directrices políticas que le impulsen, siempre, claro estí, que no exceda de los límites impuestos por las propias normas constitucionales. Quiere ello decir que ante una ordenación normativa de un derecho de carácter restrictivo, bien que respetuosa con las exigencias constitucionales, la cláusula del Art. 10.2 salva en todo caso el que el contenido del derecho se acomode a la regulación dada al mismo por el Derecho convencional, lo que entraña una garantía que, en ocasiones, se ha revelado como de gran utilidad. 
tenderse con Ríos Alvare $z^{60}$ que la dignidad de la persona puede tener un contenido integrador del vacío que pueda ocasionar la omisión o la falta de reconocimiento de un derecho indispensable para la preservación del ser humano.

c/ por último, una función hermenéutica, de acuerdo con la cual el Art. 10.1 opera como pauta interpretativa de todas las normas ordinamentales, correspondiendo a todos los poderes públicos la evaluación del significado objetivo de las diversas disposiciones normativas, sea cual sea su índole, y, consecuentemente, aplicándolas y ejecutándolas con estricta fidelidad a los valores y principios definidos en este Art. 10.1. Esta función interpretativa no es, en último término, sino una derivación más del carácter que con anterioridad atribuimos a la dignidad de la persona humana, de principio rector supremo del ordenamiento jurídico. En esta misma dirección, el Tribunal Constitucional, en un recurso de amparo, aun cuando descartando "a limine» la contrastación aislada de las resoluciones impugnadas con, entre otros, el Art. 10.1, por entender que está excluido del ámbito material de amparo constitucional, ha admitido de modo explícito e inequívoco la virtualidad interpretativa del artículo 10.1 de nuestra Norma Suprema ${ }^{61}$.

\section{La dignidad de la persona y los derechos fundamentales}

\section{A) La dignidad como fuente de todos los derechos}

En la República Federal Alemana se viene discutiendo desde antaño acerca de si la dignidad de la persona, que, como vimos, proclama el Art. 1 ‥ 1 de la "Grundgesetz", es o no un derecho fundamental. Y así, para Stein ${ }^{62}$, mientras el Art. $2^{2} .1$ (a cuyo tenor: "Todos tienen derecho al libre desenvolvimiento de su personalidad siempre que no vulnere los derechos de otro ni atente al orden constitucional o a la ley moral»), norma que a su juicio dice fundamentalmente lo mismo que el Art. $1^{\circ} .1$, incorpora un verdadero derecho fundamental, el Art. $1^{\circ} .1$ consiste sólo en una norma constitucional objetiva que no concede a los particulares ningún derecho subjetivo. Bien es verdad que incluso desde esta

60 Ríos Alvartz, Lautaro, "La dignidad de la persona en el ordenamiento juridico español", en el colectivo, XV Jornadas Chilenas de Derecho Público, Universidad de Valparaíso, 1985, pp. 173 y ss.; en concreto, p. 205.

61 STC $137 / 1990$, de 19 de julio, fund. jur. $3^{\circ}$.

62 STEIN, Ekkehart, Derecho Político. Op. cit., p. 236. 
perspectiva, a través del Art. $2^{\circ} .1$, que contiene una garantía de la libertad general de actuar, es decir, del derecho a hacer y no hacer lo que se quiera $^{63}$, encontraría en alguna medida recepción constitucional entre los derechos fundamentales el derecho a la dignidad personal.

Con todo, no se puede ignorar que el Art. $1^{\circ} .1$ es la norma de apertura del Capítulo primero de la Ley Fundamental de Bonn, cuyo rótulo es "Die Grundrechte", esto es, «De los derechos fundamentales», por lo que, por pura lógica, bien debiera entenderse que todos y cada uno de los diecinueve artículos que acoge este Capítulo enuncian verdaderos derechos fundamentales, susceptibles todos ellos, caso de una supuesta violación, de dar lugar a un recurso de queja constitucional (Verfassungsbeschwerden). No debe extrañar por lo mismo que Durig ${ }^{64}$ entienda que en la idea de los padres de la Constitución el derecho fundamental de la dignidad de la persona humana no debería ser «calderilla». Y Von Munch ${ }^{65}$, con cierta claridad, habla de un derecho fundamental de la dignidad de la persona humana, que se protege como derecho del hombre, esto es, de todo ser humano.

En España, la polémica surgida en Alemania carece de cualquier sustento. Es cierto que en el Art. 10.1 se sitúa en el frontispicio del título primero, relativo a los derechos y deberes fundamentales, y por tanto dentro del mismo, y desde este punto de vista podría aducirse que estamos ante un derecho fundamental cuando nos referimos a la dignidad de la persona. Pero hay dos aspectos relevantes que han de ser tenidos en cuenta: de un lado, la sistemática del Título, dividido en cinco Capítulos cuyos rótulos reflejan que no en todos ellos se acoge la enunciación de derechos, por lo que de la mera inserción en el Título no debe desprenderse que estemos ante la proclamación de un derecho fundamental, y de otro, que el Art. 53 ${ }^{\circ}$, al enumerar las garantías de los derechos, se limita a contemplar los derechos del capítulo $2^{\circ}$ y los derechos (mal llamados principios) del capítulo $3^{\circ}$. Más aún, el hecho de que el Art. $10^{\circ}$ se ubique al margen de los cinco capítulos en que se estructura el Título nos revela la intención del constituyente de enunciar más que unos derechos, unos principios rectores no ya del conjunto de los derechos y libertades que se enuncian en los artículos subsiguientes, sino, más ampliamente, del ordenamiento jurídico en su conjunto.

\footnotetext{
6.3 Ibidem, p. 215.

64 Durig, G., en Archip des offentlichen Rechts, vol. 81, 1956, p. 117 y ss.; en concreto, p. 124. Cit. por Ingo Von Munch: La dignidad del bombre en el Derecbo Constitucional. Op. cit., p. 12.

65 Von Munch, Ingo, La dignidad del hombre... Op. cit., pp. 13 y 15.
} 
El Tribunal Constitucional ha corroborado esta tesis, rechazando que la dignidad de la persona, "per se", pueda ser considerada como un derecho fundamental. Y así, en el recurso de amparo $\mathrm{N} N 443 / 1990$, frente a la argumentación del demandante en relación con la supuesta infracción, por violación de la dignidad de la persona, del Art. 10.1 de la Constitución, el Alto Tribunal razonará que sólo en la medida en que los derechos individuales sean tutelables en amparo y únicamente con el fin de comprobar si se han respetado las exigencias que, no en abstracto, sino en el concreto ámbito de cada uno de aquellos, deriven de la dignidad de la persona, habrá de ser ésta tomada en consideración por el Tribunal como referente. No en cambio, de modo autónomo para estimar o desestimar las pretensiones de amparo que ante él se deduzcan ${ }^{66}{ }^{67}$.

Esta doctrina jurisprudencial lo que nos quiere decir es que de la dignidad de la persona dimanan unas exigencias mínimas en el ámbito de cada derecho en particular, o como afirma el Tribunal, y ya tuvimos oportunidad de recordar en un momento precedente, un "minimum invulnerable" que todo estatuto jurídico debe asegurar.

Pero si es claro que en nuestro ordenamiento constitucional, la dignidad de la persona no puede ser entendida como derecho fundamental, no lo es menos que la dignidad puede ser considerada como la fuente de todos los derechos.

Esta idea ha sido acogida por la doctrina de otros países. Y así, para Von Munch ${ }^{68}$, es interesante desde el punto de vista dogmático la idea de que en todos y cada uno de los derechos fundamentales se manifiesta un «núcleo de existencia humana» derivado de la dignidad de la persona. Y Miranda ${ }^{69}$ entiende de modo directo y evidente que los derechos, libertades y garantías personales, al igual que los derechos, económicos, sociales y culturales encuentran su fuente ética en la dignidad de la persona, de todas las personas.

Y ya en relación con nuestro ordenamiento, Ríos Alvare $z^{70}$ ha po-

66 STC $120 / 1990$, de 27 de junio, fund. jur. $4^{\circ}$.

67 En su Sentencia 184/1990, de 15 de noviembre, el Alto Tribunal considerará evidente que el Art. 10.1 no puede en modo alguno servir de fundamento, por sí solo y aisladamente considerado, del derecho a percibir pensión de viudedad en favor de uno de los que convivían extramatrimonialmente cuando el otro fallece (fund. jur. $2^{\circ}$ ).

${ }_{68}$ Von Munch, Ingo, La dignidad del hombre... Op. cit., p. 15.

69 Miranda, Jorge, Manual de Direito Constitucional, tomo IV (Direitos fundamentais). Op. cit., p. 167.

70 Ríos Alvarez, Lautaro, La dignidad de la persona en el ordenamiento jurídico español. Op. cit., p. 205. 
dido afirmar que la dignidad de la persona es la fuente directa y la medida trascendental del contenido de los derechos fundamentales reconocidos, en especial, de los llamados «derechos de la personalidad». Pero no agota allí su inmanencia: es fuente residual del contenido de cualquier derecho imperfectamente perfilado o insuficientemente definido, en cuanto ese contenido sea necesario para el libre y cabal desarrollo de la personalidad.

Por lo demás, la idea creemos que está latente con cierta nitidez en el mismo texto del Art. 10.1, que deja claro que de la dignidad de la persona dimanan unos derechos inviolables que son inherentes a aquella.

Como razona Hernández $\mathrm{Gil}^{71}$, es muy significativo y coherente con la imagen que la Constitución ofrece de la persona el hecho de que la categoría antropológico ética de la dignidad aparezca antepuesta, afirmada "per se" y no como una derivación de los derechos. De ello entresaca el citado auto que la persona no es el resultado de los derechos que le corresponden; luego, aun sin derechos, la persona existe en cuanto tal; por lo mismo, los derechos le son inherentes, traen de ella su causa; son exigibles por la dignidad de la persona.

En definitiva, dignidad y derechos no se hallan en el mismo plano ${ }^{72}$. La dignidad se proclama como valor absoluto, con lo que ello entraña de que incluso a una persona que se comporte indignamente deba reconocérsele igual dignidad que a cualquier otra, como ya advertimos en otro momento. Y por lo mismo, la dignidad se convierte en la fuente de los derechos, de todos los derechos independientemente de su naturaleza, de la persona, que dimanan de esa dignidad inherente a todo ser humano.

\section{B) Igualdad en dignidad y titularidad de derechos}

La dignidad, como acabamos de señalar, se proclama en el Art. 10.1 en

\footnotetext{
71 Hernández Gil, Antonio, El cambio politico español y la Constitución. Op. cit., p. 422 .

72 El contraste podríamos encontrarlo en el Pacto Internacional de Derechos Civiles y Políticos, suscrito en Nueva York el 16 de diciembre de 1966, en cuyo Préámbulo (párrafo primero) puede leerse: "Considerando que, conforme a los principios entnciados en la Carta de las Naciones Unidas, la libertad, la justicia y la paz en el mundo tienen por base el reconocimiento de la dignidad inherente a todos los miembros de la familia humana y de sus derechos iguales e inalienables». Es evidente que aquí dignidad y derechos se colocan en idéntico plano.
} 
términos absolutos, esto es, no depende ni de la nacionalidad ni de ninguna otra circunstancia personal. Bien podríamos traer a colación aquí el Art. $1^{\circ} .2$ de la Convención Americana sobre Derechos Humanos, suscrita en San José de Costa Rica el 22 de noviembre de 1969, a cuyo tenor: "Para los efectos de esta Convención, persona es todo ser humano». Pues bien, para los efectos que aquí nos ocupan, la dignidad es predicable de todo ser humano sin matiz diferencial alguno.

La doctrina social de la Iglesia es un buen ejemplo de constancia e insistencia acerca de este punto fundamental. Y así, por recordar algunos mensajes de esta doctrina, podemos hacernos eco de cómo en la Encíclica del Papa Juan XXIII "Pacem in Terris" puede leerse: "Hoy se ha extendido y consolidado por doquier la convicción de que todos los hombres son por dignidad natural, iguales entre sím. Y en la Constitución Pastoral del Concilio Vaticano II "Gaudium et Spes» se dedica un capítulo (Capítulo primero de la Parte primera) a la dignidad de la persona humana. Más allá del mismo, en el parágrafo 29, se afirma:

"Como todos los hombres, dotados de alma racional y creados a imagen de Dios, tienen la misma naturaleza y el mismo origen, y como, redimidos por Cristo, gozan de una misma vocación y de un mismo destino divino, se debe reconocer más y más la fundamental igualdad entre todos.

Cierto que no todos los hombres se equiparan por su variada capacidad física y por la diversidad de las fuerzas intelectuales y morales. No obstante, toda forma de discriminación, ya sea social o cultural, en los derechos fundamentales de la persona, por el sexo, raza, color, condición social, lengua o religión, ha de ser superada y rechazada como contraria a los designios de Dios...

Además, aunque hay justas diferencias entre los hombres, la igual dignidad de las personas exige que se llegue a una más humana y justa condición de vida. Pues demasiado grandes desigualdades económicas y sociales entre los miembros o los pueblos de una misma familia humana llevan al escándalo y se oponen a la justicia social, a la equidad, a la dignidad de la persona humana, así como a la paz social e internacional» ${ }^{73}$.

En definitiva, para la doctrina social de la Iglesia, hay una dignidad

73 Los textos citados pueden verse en «El Mensaje Social de la Iglesia» Documentos MC, 2a. ed., Ediciones Palabra, Madrid, 1987. 
natural predicable respecto de todo hombre, de todo ser humano, que se traduce en la igualdad esencial entre todos ellos y de la que dimanan unas exigencias insoslayables en el plano de los derechos fundamentales, entendiendo esta expresión no en un sentido técnico-jurídico, y por lo mismo incluyendo dentro de ellos los derechos de naturaleza social y económica.

Si recordamos ahora los cuatro niveles o dimensiones de la dignidad personal a que aludiera Ruiz-Giménez, podríamos con el propio autor ${ }^{74}$ entresacar algunas importantes consecuencias de esas dimensiones plurales que nos ofrece la dignidad del ser humano:

a/ En primer término, que la «dignidad básica o radical de la persona» no admite discriminación alguna dada la igualdad esencial de todos los seres humanos.

b/ En segundo lugar, que la dignidad ontológica, esto es, la que corresponde al hombre como ser dotado de inteligencia, racionalidad y libertad, no está ligada ni a la edad ni a la salud mental de la persona, que tienen, sin duda, incidencia en ciertos aspectos jurídicos de la capacidad de obrar, pero no en la personalidad profunda.

c/ Tampoco el ser humano que decae en su vida moral o, incluso, comete hechos tipificados como delitos en el ordenamiento jurídico-penal, pierde por eso su dignidad ontológica.

d/ Por último, por convergentes razones, la «dignidad básica» de la persona trasciende las fronteras territoriales y ha de ser respetada no sólo a los ciudadanos de un Estado, sino también a los extranjeros.

De esta última consecuencia ha tenido oportunidad de hacerse eco entre nosotros el «intérprete supremo de la Constitución». En su Sentencia 107/1984, el Alto Tribunal abordó la problemática de la titularidad o capacidad de los derechos fundamentales, ciñéndose a la cuestión de la titularidad de tales derechos por los extranjeros. Tras admitir que aunque los derechos y libertades reconocidos a los extranjeros son derechos constitucionales y, por lo mismo, dotados de la protección constitucional el Tribunal precisaría que todos ellos sin excepción son en cuanto a su contenido "derecho de configuración legal», para razonar de inmediato como sigue:

«Esta configuración puede prescindir de tomar en considera-

74 Ruiz-Gimínez Cortés, Joaquín, Derechos fundamentales de la persona. Op. cit., pp. $115-116$. 
ción, como dato relevante para modular el ejercicio del derecho, la nacionalidad o ciudadanía del titular, produciéndose así una completa igualdad entre españoles y extranjeros, como la que efectivamente se da respecto de aquellos derechos que pertenecen a la persona en cuanto tal y no como ciudadano, o, si se rehuye esta terminología, ciertamente equívoca, de aquellos que son imprescindibles para la garantía de la dignidad humana que, conforme al Art. 10.1 de nuestra Constitución, constituye fundamento del orden político. Derechos tales como el derecho a la vida, a la integridad física y moral, a la intimidad, la libertad ideológica, etc., corresponden a los extranjeros por propio mandato constitucional, y no resulta posible un tratamiento desigual respecto a ellos en relación a los españoles $»^{75}$.

La doctrina jurisprudencial es, pues, inequívoca: todos aquellos derechos que son imprescindibles para garantizar la dignidad humana han de corresponder por igual a españoles y extranjeros, debiendo ser su ordenación normativa idéntica para unos y otros. En definitiva, en estos derechos la "dignidad básica» del ser humano exige la plena titularidad de los mismos sin distingo alguno.

Otra cuestión que se ha suscitado ante nuestro «intérprete supremo de la Constitución» es la relativa a la titularidad de derechos por parte de personas jurídicas.

Aunque, como bien advierte Von Munch en relación con la República Federal de Alemania, ni los órganos del Estado ni tampoco las personas jurídicas de derecho privado pueden ser titulares del derecho fundamental de la dignidad de la persona humana, pues este derecho sólo tiene vigencia para las personas en cuanto individuos a causa de su vinculación a la existencia única e irrepetible del individuo ${ }^{76}$, no es menos cierto que se podría admitir alguna extensión analógica del concepto de "dignidad» a las personas colectivas (morales o jurídicas), en la medida en que como recuerda Ruiz-Giménez ${ }^{77}$, esas "personas colectivas» integran a personas humanas individuales, persiguen fines humanos y logran una suficiente cohesión interna, mediante la cooperación estable de todos sus miembros. Y a partir de esta reflexión, cabría

75 STC $107 / 1984$, de 23 de noviembre, fund. jur. $3^{\circ}$. Esta doctrina será reiterada en la STC $99 / 1985$, de 30 de septiembre, fund. jur. $2^{\circ}$.

76 Von Munch, Ingo, La dignidad del bombre... Op. cit., p. 17.

77 Ruiz-Gimfinfz Cortís, Joaquín, Derechos fundamentales de la persona. Op. cit., p. 116. 
admitir la titularidad de ciertos derechos por parte de aquellas personas colectivas.

Pues bien, como antes advertimos, el Tribunal Constitucional tuvo oportunidad de pronunciarse sobre esta materia en su Sentencia 64/ 1988, en la que razonará como sigue ${ }^{78}$ :

«Es indiscutible que, en línea de principio, los derechos fundamentales y las libertades públicas son derechos individuales que tienen al individuo por sujeto activo y al Estado por sujeto pasivo en la medida en que tienden a reconocer y proteger ámbitos de libertades o prestaciones que los poderes públicos deben otorgar o facilitar a aquellos. Se deduce así, sin especial dificultad, del Art. 10 de la Constitución que, en su apartado primero, vincula los derechos inviolables con la dignidad de la persona y con el desarrollo de la personalidad y, en su apartado segundo, los conecta con los llamados derechos humanos, objeto de la Declaración Universal y diferentes tratados y Acuerdos Internacionales ratificados por España.

Es cierto, no obstante, que la plena efectividad de los derechos fundamentales exige reconocer que la titularidad de los mismos no corresponde sólo a los individuos aisladamente considerados, sino también en cuanto se encuentran insertos en grupos y organizaciones, cuya finalidad sea específicamente la de defender determinados ámbitos de libertad o realizar los intereses y valores que forman el sustrato último del derecho fundamental».

El Alto Tribunal ha venido de esta forma a admitir la titularidad de derechos de estas personas colectivas, con una argumentación que bien puede considerarse, al unísono, que, de un lado, admite un cierto trasfondo de "dignidad ontológica» de las personas colectivas, mientras que, de otro, parece sustentarse en la idea de que el reconocimiento de la titularidad de derechos a los grupos en que se insertan los individuos supone una profundización en la efectividad de los derechos fundamentales y, por lo mismo, se vincula, en último término, con la propia dignidad de todo ser humano. Este último argumento creemos que subyace con cierta nitidez en la amplia concepción con que el Alto Tribunal reconoció la legitimación activa para recurrir en vía de amparo constitucional en relación a un derecho tan personalísimo como es el derecho al 
honor. En efecto, en su Sentencia 214/1991, el Tribunal razonaba de la siguiente forma ${ }^{77}$ :

«Tratándose de un derecho personalísimo, como es el honor, la legitimación activa corresponderá en principio, al titular de dicho derecho fundamental. Esta legitimación originaria no excluye, ni la existencia de otras legitimaciones, ni que haya de considerarse también como legitimación originaria la de un miembro de un grupo étnico o social determinado, cuando la ofensa se dirigiera contra todo ese colectivo, de tal suerte que, menospreciando a dicho grupo socialmente diferenciado, se tienda a provocar en el resto de la comunidad social sentimientos hostiles o, cuando menos, contrario a la dignidad, estima personal o respeto al que tienen derecho todos los ciudadanos con independencia de su nacimiento, raza o circunstancia personal o social» ${ }^{80}$.

\section{C) Derechos Inherentes a la dignidad}

La dignidad, como ya expusimos, es la fuente de todos los derechos; de ahí que de ella haga dimanar el Art. 10.1 unos derechos inviolables «que le son inherentes». Como ha dicho el Tribunal Constitucional ${ }^{81}$, «el valor jurídico fundamental de la dignidad de la persona», indisolublemente relacionado con el derecho a la vida en su dimensión humana, es reconocido en el Art. 10.1 como germen o núcleo de unos derechos que le son inherentes. La relevancia y significación superior de uno y otro valor y de los derechos que los encarnan se manifiesta en su colocación misma en el texto constitucional, ya que el Art. 10 es situado a la cabeza del Título destinado a tratar de los derechos y deberes fundamentales.

A partir de la precedente reflexión, se suscita la cuestión de cuáles son los derechos inherentes a la dignidad del ser humano. Garrido Fa$11 a^{82}$, a partir de un argumento tan formalista como el de la diferente

70 STC 214/1991, de 11 de noviembre, fund. jur. $3^{2}$.

8) En la misma Sentencia 214/1991, el Tribunal afirma en otro momento (fundamento jurídico $8^{\circ}$ ) que uel odio y el desprecio a todo un pueblo o a una etnia (a cualquier pueblo o cualquier etuia) son incompatibles con el respeto a la dignidad humana, que sólo se cumple si se atribuye por igual a todo hombre, a toda etnia, a todos los pueblos".

*1 STC 53/1985, de 11 de abril, fund. jur. $3^{2}$.

x2 Garrido Falla, Fernando, "Comentario al articulo 10 de la Constitución" en el 
protección jurídica de los derechos que proporciona el Art. $53^{\circ}$ de la "Lex Superior", responde a nuestro anterior interrogante afirmando que los derechos inviolables que son inherentes a la persona son sólo los comprendidos en los artículos $15^{\circ}$ a $29^{\circ}$ de la Constitución (y en el $30^{\circ}$ por lo que se refiere al derecho a la objeción de conciencia). No podemos desde ningún punto de vista suscribir esta interpretación, que carece de toda sustancia material, mientras que, a nuestro juicio, este contenido material, esto es, el núcleo axiológico de la Norma Suprema ha de impregnar todos y cada uno de los preceptos constitucionales.

Como afirma Maritain ${ }^{83}$, el hecho crucial de nuestro tiempo es que la razón humana ha tomado ahora conciencia, no sólo de los derechos del hombre en cuanto persona humana y persona cívica, sino también de sus derechos en cuanto persona social implicada en el proceso económico y cultural, y, especialmente, de sus derechos como persona obrera. En definitiva, añadiríamos nosotros, hoy existe una conciencia social respecto a la ineludibilidad de contribuir al desarrollo integral de todo ser humano. $Y$ es evidente que ese desarrollo integral o, como dice el Art. 10.1 el libre desarrollo de la personalidad, exige atender a todos y cada uno de los derechos de que es titular el hombre en las distintas dimensiones que su vida presenta. Por lo mismo, aun cuando podamos establecer una serie de graduaciones, creemos que todos y cada uno de los derechos que la Constitución enuncia en el Título I son, en mayor o menor grado, inherentes a la persona y a su dignidad radical. Por lo mismo, a nuestro entender, también los derechos que acoge el Capítulo $3^{\circ}$ del Título I (bajo el no muy afortunado rótulo de "principios rectores de la política social y económica») han de vincularse con la dignidad personal. ¿No exige la dignidad de toda persona ubicada generacionalmente dentro de lo que se a dado en llamar tercera edad de unas determinadas prestaciones de los poderes públicos, a las que alude el Art. 50?. La respuesta es tan obvia y la generalización de ejemplos que podrían aducirse tan patente, que nos exime de cualquier reflexión adicional.

Pero incluso desde una óptica más formal, la ubicación del Art. 10, en el frontispicio del Título I, y como artículo aislado de los Capítulos en que se sistematiza el Título en cuestión, ofrece una apoyatura bastante sólida en la que sustentar la proyección general de la dignidad hacia

colectivo dirigido por él mismo, Comentarios a la Constitución, Civitas, 2a. ed., Madrid, 1985, pp. 185 y ss.; en concreto, p. 187.

${ }_{83}$ Maritain, Jacques, El hombre y el Estado, Fundación Humanismo y Democracia Encuentro Ediciones, Madrid, 1983, p. 121. 
todos los derechos del Título, con independencia de cual sea la eficacia jurídica de las normas en que aquellos se recogen. En definitiva, en mayor o menor medida, todos los derechos del Título I dimanan de la dignidad de la persona y, por lo mismo, son inherentes a ella. Y ello debe tener su trascendencia jurídica, sin ir más lejos, por ejemplo, a efectos hermenéuticos.

Un ejemplo jurisprudencial de una interpretación amplia de este valor jurídico supremo que es la dignidad de la persona, lo encontramos en las Sentencias 113/1989 y 158/1993, en las que el Alto Tribunal legitima la existencia de ciertos límites que pesan sobre los derechos patrimoniales en el respeto a la dignidad de la persona humana.

En la primera de esas sentencias, el Juez de la Constitución entiende que los valores constitucionales que conceden legitimidad al límite que la inembargabilidad impone al derecho del acreedor a que se cumpla la Sentencia firme que le reconoce el crédito se encuentran en el respeto a la dignidad humana, configurado como el primero de los fundamentos del orden político y de la paz social en el Art. 10.1, a cuyo fin resulta razonable y congruente crear una esfera patrimonial intangible a la acción ejecutiva de los acreedores que coadyuve a que el deudor pueda mantener la posibilidad de una existencia digna ${ }^{84}$.

Insistiendo en similar dirección, en la Sentencia $158 / 1993^{85}$, el Alto Tribunal considera que las normas de inembargabilidad de salarios y pensiones -que, en muchas ocasiones, son la única fuente de ingresos económicos de gran número de personas-, constituyen límites legislativos a la embargabilidad que tienen, en principio con carácter general, una justificación constitucional inequívoca en el respeto a la dignidad de la persona humana, "principio al cual repugna que la efectividad de los derechos patrimoniales se lleve al extremo de sacrificar el mínimo económico vital del deudor». Este respeto a la dignidad de la persona justifica, así, la creación legislativa de una esfera patrimonial inmune a la acción ejecutiva de los acreedores.

Esta jurisprudencia debería marcar un ejemplo a seguir. La dignidad de la persona, como valor supremo del ordenamiento jurídico, exige una mayor sensibilización hacia los llamados derechos sociales. Como ha dicho con evidente razón Frosini ${ }^{86}$, el progreso de la civilización humana

84 STC $113 / 1989$, de 22 de junio, fund. jur. $3^{\circ}$.

8.5 STC 158/1993, de 6 de mayo, fund. jur. $3^{\circ}$.

86 Frosini, Vittorio, "Los derechos bumanos en la sociedad tecnológica", en Anuario de Derechos Humanos, $N^{2} 2$, Universidad Complutense, Madrid, 1983, pp. 101 y ss.; en concreto, p. 107. 
se mide sobre todo en la ayuda dada por el más fuerte al más débil, en la limitación de los poderes naturales de aquel como reconocimiento de las exigencias morales de éste, en el aumento del sentido de una fraternidad humana sin la cual los derechos a la libertad se convierten en privilegios egoístas y el principio de igualdad jurídica, en una nivelación basada en el sometimiento al poder del más fuerte. Es preciso, pues, que esos derechos que Bidart Campos ${ }^{87}$ ha denominado «imposibles», esto es, aquellos que un hombre no alcanza a ejercer y gozar, encuentren un remedio efectivo. Así lo exige la dignidad radical de todo ser humano.

Y por lo demás, aunque del tenor del inciso final del Art. 53.3 de la Constitución resulta claro que los mal denominados «principios rectores de la política social y económica no constituyen derecho inmediatamente aplicable», no es menos evidente que de ello no debe inferirse que los principios del Capítulo $3^{\circ}$ no generen ningún tipo de obligaciones para los poderes públicos. El inciso primero del propio precepto certifica lo contrario ( $\mathrm{El}$ reconocimiento, el respeto y la protección de los principios reconocidos en el Capítulo $3^{\circ}$ informarán la legislación positiva, la práctica judicial y la actuación de los poderes públicos»). Y en la interpretación de estos derechos, de estos principios, que, llegado el caso, deban realizar los órganos jurisdiccionales, se habrá de tener muy presente que también sobre ellos se ha de proyectar el valor jurídico supremo de la dignidad, que exige, como ya vimos, de un "minimun invulnerable» que todo estatuto jurídico debe asegurar.

En otro orden de consideraciones, en análisis de la jurisprudencia del Tribunal Constitucional pone de relieve una constante vinculación de un grupo más o menos amplio de derechos a la dignidad de la persona, sin que, a nuestro entender, de ello deba inferirse que sólo esos y tan sólo esos derechos han de considerarse inherentes a la dignidad del ser humano.

En su Sentencia 53/1985, el Alto Tribunal entendía que la dignidad de la persona se halla íntimamente vinculada con el libre desarrollo de la personalidad (Art. $10^{\circ}$ ) y los derechos a la integridad física moral

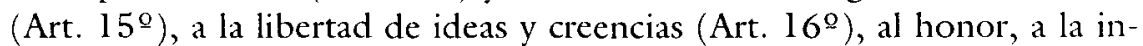
timidad personal y familiar y a la propia imagen (Art. 18.1 ( $^{88}$.

Especialmente insistente ha sido la consideración jurisprudencial de que el derecho al honor y los derechos a la imagen y a la intimidad per-

87 Bidart Campos, Germán J., Tratado Elemental de Derecho Constitucional Argentino, Tomo I ( El Derecho Constitucional de la Libertad»). Ediar, Buenos Aires, 1986, p. 210.

88 STC $53 / 1985$, de 11 de abril, fund. jur. $8^{\circ}$. 
sonal y familiar reconocidos en el Art. 18.1 aparecen como derechos fundamentales estrictamente vinculados a la propia personalidad y derivados sin duda de la dignidad de la persona ${ }^{89}$. «La intimidad personal y familiar -razona en otro momento el Juez de la Constitución ${ }^{90}-$ es un bien que tiene la condición de derecho fundamental y sin el cual no es realizable, ni concebible siquiera, la existencia en dignidad que a todos quiere asegurar la Norma Fundamental». Estos derechos a la imagen y a la intimidad personal y familiar, en cuanto derivados sin duda de la dignidad de la persona, «implican la existencia de un ámbito propio y reservado frente a la acción y conocimiento de los demás, necesario -según las pautas de nuestra cultura-, para mantener una calidad mínima de la vida humana. Se muestran así esos derechos como personalísimos y ligados a la misma existencia del individuo»" ${ }^{91}$. Ahora bien, si el atributo más importante de la intimidad, como núcleo central de la personalidad, es la facultad de exclusión de los demás, de abstención de injerencias por parte de otro, tanto en lo que se refiere a la toma de conocimientos intrusiva, como a la divulgación ilegítima de esos datos, entiende el Tribunal ${ }^{93}$ que «la conexión de la intimidad con la libertad y dignidad de la persona implica que la esfera de inviolabilidad de la persona frente a injerencias externas, el ámbito personal y familiar, sólo en ocasiones tenga proyección hacia el exterior, por lo que no comprende en principio los hechos referidos a las relaciones sociales y profesionales en que se desarrolla la actividad laboral».

Por el contrario, alguno de los derechos acogidos por la Sección primera del Capítulo $2^{\circ}$ del Título I no ha sido considerado imprescindible para la garantía de la dignidad humana. Tal es el caso de la libertad de circulación a través de las fronteras del Estado y el concomitante de-

49) Entre otras muchas, SSTC $231 / 1988$, de 2 de diciembre, fund. jur. 3\%; $197 /$ 1991, de 17 de octubre, fund. jur. $3^{\circ}$, y 214/1991, de 11 de noviembre, fund. jur. $1^{\circ}$.

(1) STC $20 / 1992$, de 14 de febrero, fund. jur. $3^{\circ}$.

y) STC $231 / 1988$, de 2 de diciembre, fund. jur. $3^{\circ}$.

"2 Desarrollando su doctrina, entiende el Tribunal (STC 20/1992, de 14 de febrero, fund. jur. $3^{0}$ ) que aunque no todo alegato en defensa de lo que se diga vida privada será merecedor de tal aprecio y protección, sí es preciso reiterar que la preservación de ese "reducto de inmunidad", sólo puede ceder, cuando del derecho a la información se trata, si lo difundido afecta, por su objeto y por su valor, al ámbito de lo público, no coincidente, claro es, con aquello que pueda suscitar o despertar, meramente, la curiosidad ajena. Y en otro momento (STC 197/1991, de 17 de octubre, fund. jur. $3^{\circ}$ ) cree el tribunal que desde la perspectiva de la dignidad de la persona, no cabe duda que la filiación, y muy en particular la identificación del origen de un adoptado, ha de entenderse que forma parte de ese ámbito propio y reservado de lo íntimo. 
recho a residir dentro de ellas, derechos que, al no ser imprescindibles para la garantía de la dignidad humana, no pertenecen a todas las personas en cuanto tales al margen de su condición de ciudadanos ${ }^{94}$.

Y en la otra cara de la moneda hemos de situar la reflexión jurisprudencial que amplía el marco jurídico del Art. 39.1, norma de apertura del Capítulo $3^{\circ}$ del Título I, a cuyo tenor, «los poderes públicos aseguran la protección social, económica y jurídica de la familia". Pues bien, según el Alto Tribunal ${ }^{95}$, en correspondencia con el pluralismo de opciones personales existente en la sociedad española y con la preeminencia que posee el libre desarrollo de la personalidad-que, como ya apuntamos en un momento anterior, da un carácter concreto, individualizado, al conjunto de derechos que dimanan de la dignidad del ser humano-, la Constitución no sólo protege a la familia que se constituye mediante el matrimonio, sino también a la familia como realidad social, entendida por tal la que se constituye voluntariamente mediante la unión de hecho, efectiva y estable, de una pareja.

Creemos que la jurisprudencia comentada pone de relieve, por lo menos de modo incipiente, que, con mayores o menores matices o inflexiones, la dignidad del ser humano se manifiesta, se proyecta, de una u otra forma, con distintos niveles de intensidad, en todos y cada uno de los derechos que el Título I de la Constitución enuncia, bien se presenten bajo el rótulo de auténticos derechos, bien bajo el de principios rectores. Este es, creemos, el camino a seguir, que debe tener como norte, a nuestro entender, el que las violaciones más brutales de la dignidad esencial, radical, de todos los seres humanos, cada vez se presentan de forma más ostentosa y clamorosa en los llamados derechos sociales o socio-económicos, cuya conculcación sistemática, más por los particulares que por los poderes públicos, revela altísimos niveles de insolidaridad social ante los que los poderes públicos no pueden permanecer impasibles, siquiera sea por el inequívoco y fundamental mandato constitucional del Art. $9^{\circ} .2$ de nuestra Norma Suprema. 


\section{D) La Dignidad de la persona como freno frente al ejercicio abusivo de los derechos}

La elevación de la dignidad de la persona y de los derechos que le son inherentes a la categoría de fundamento del orden político y de la paz social no significa, como ya tuvimos oportunidad de señalar, que todos los derechos, ni siquiera los fundamentales, sean "in toto" condiciones imprescindibles para la efectiva incolumidad de la dignidad personal, de modo que de cualquier restricción que a su ejercicio se imponga devenga un estado de indignidad. En definitiva, no hay derechos ilimitados y menos aún pueden ejercerse los derechos abusivamente. Y en este orden de consideraciones, la dignidad ha venido a operar como un límite frente al ejercicio abusivo de los derechos. Así se ha decantado en diferentes supuestos en la jurisprudencia constitucional.

Ya en una de sus primeras sentencias, el Tribunal consideraba ${ }^{96}$ que ni la libertad de pensamiento ni el derecho de reunión y manifestación comprenden la posibilidad de ejercer sobre terceros una violencia moral de alcance intimidatorio, porque ello es contrario a bienes constitucionalmente protegidos como la dignidad de la persona y su derecho a la integridad moral, que han de respetar no sólo los poderes públicos, sino también los ciudadanos.

Han sido, sin embargo, las libertades informativas las que en mayor medida se han visto delimitadas en su ejercicio abusivo por el valor jurídico supremo del ordenamiento por la dignidad de la persona. La doctrina del Tribunal puede ser compendiada del siguiente modo:

a/. Rechazo de la emisión de apelativos formalmente injuriosos en cualquier contexto, en cuanto que no sólo son innecesarios para la labor informativa o de formación de la opinión, sino que, además y principalmente, suponen un daño injustificado a la dignidad de las personas o al prestigio de las instituciones, habiendo de tenerse en cuenta asimismo que la Constitución no reconoce un pretendido derecho al insulto, que sería por lo demás incompatible con la dignidad de la persona ${ }^{97}$.

b/. Rechazo de la emisión de imágenes que conviertan en instrumento de diversión y entretenimiento algo tan personal como los padecimientos y la misma muerte de un individuo, al entender que ello se

\footnotetext{
$\%$ STC $2 / 1982$, de 29 de enero, fund. jur. $5^{\circ}$.

97 STC $105 / 1990$, de 6 de junio, fund. jur. $8^{\circ}$.
} 
encuentra en clara contradicción con el principio de la dignidad de la persona ${ }^{98}$.

c/. Rechazo a la tesis de que la libertad ideológica del Art. $16^{\circ}$ de la Constitución, o la libertad de expresión del Art. 20.1, comprendan el derecho a efectuar manifestaciones, expresiones o campañas de carácter racista o xenófobo, puesto que ello es contrario no sólo al derecho al honor de la persona o personas directamente afectadas, sino a otros bienes constitucionales como el de la dignidad humana, que han de respetar tanto los poderes públicos, como los propios ciudadanos. La dignidad como rango o categoría de la persona como tal, del que deriva y en el que se proyecta el derecho al honor, no admite discriminación alguna por razón de nacimiento, raza o sexo, opiniones o creencias ${ }^{99}$.

En resumen, y ya para finalizar, es evidente que los derechos fundamentales vinculan también a los particulares, y no sólo a los poderes públicos, y es claro asimismo que si el respeto a los derechos de los demás, al igual que el respeto a la ley, es uno de los fundamentos del orden político y de la paz social, nunca podrá ejercerse un derecho con violación del derecho de otra persona $\mathrm{y}$, menos aún, conculcando la dignidad esencial de otro ser humano, con lo que cualquier violación de la dignidad personal producida a raíz del ejercicio de un derecho convierte dicho ejercicio en abusivo, privando a quien así actúa de toda cobertura constitucional o legal. 